\title{
The Analysis of Ecotourism Eligibility in the North Coast of Makassar
}

\author{
Andi Muhammad Akram ${ }^{1 *}$, Amin Setyo Leksono ${ }^{2}$, Aminuddin Afandhi $^{3}$, \\ Muhammad Yunus ${ }^{4}$, Risman ${ }^{4}$ \\ ${ }^{1}$ Postgraduate Program of Environmental Studies, University of Brawijaya, Malang, Indonesia \\ ${ }^{2}$ Department of Biology, Faculty of Mathematics and Natural Sciences, University of Brawijaya, Malang, Indonesia \\ ${ }^{3}$ Department of Agriculture, Faculty of Agriculture, University of Brawijaya, Malang, Indonesia \\ ${ }^{4}$ Departement of Fisheries, faculty of Fisheries and Marine Science, University Muslim Indonesia, Makassar, Indonesia
}

\begin{abstract}
Ecotourism is one of environmentally friendly tourism activities which prioritizes the aspects of nature conservation, social economic culture empowerment and aspects of learning and education. Bira village, located in the coast of Makassar, has a good mangrove potential and it can be developed as a place of mangrove ecotourism. This research aimed to analyze the potential of ecology, socio-economic and supporting infrastructure for the eligibility of developing Mangrove ecotourism at Bira village of Makassar. The research design used was survey research which was descriptive analysis through case study approach. The method used was quantitative and qualitative approach. Quantitative approach used questionnaire method while qualitative approach used in-depth interview technique and field observation. Data obtained was analyzed by weighting method, spatial analysis and AHP. The results showed that the criteria of ecological eligibility included in the category was the value of 73.99; the category of socioeconomic eligibility was in accordance with the value of 81.55 and the eligibility criteria of supporting infrastructure included in the category in accordance with the acquisition value was 77.93 .
\end{abstract}

Keywords: ecotourism, eligibility criteria, mangrove.

\section{INTRODUCTION}

The development of tourism is one of the growing economic drivers in every region of Indonesia. Scholars point out that there are several tourism developments that have concepts such as nature tourism, cultural arts, and historic buildings [1]. One of tourism parts is currently ecotourism. Ecotourism is one of environmentally friendly tourism activities which prioritizes aspects of nature conservation, aspects of socio-cultural empowerment, economics and aspects of learning and education [2]. Ecotourism is also a tourism management that prioritizes the environment and cultural values or local wisdom that exist in the community [3].

The utilization of mangrove forest for ecotourism has the potential of natural beauty and environment in the form of ecosystem component consisting of vegetation, biota or organism association, wildlife and surrounding environment [2].The function of the mangrove forest is as a habitat, spawning area, nutrient provider and etc. Other functions of mangroves

\footnotetext{
${ }^{*}$ Correspondence address:

Andi Muhammad Akram

Email : andiakram32@gmail.com

Address : Postgraduate Program, University of Brawijaya, Mayjen Haryono 169, Malang 65145.
}

are as a place of research, education and ecotourism [4].

Ecotourism development is a concept of sustainable tourism development that aims to support environmental conservation efforts (nature and culture) and increases community participation in management, thus provides economic benefits to the community [5]. Sustainable ecotourism development aims to provide a quality experience to the travelers and to improve the quality of life of local communities. Most of ecotourism destinations are located in remote area. Hence, the development of ecotourism requires several strategies including increasing promotion, preserving the environment and involving the community in tourism development $[6,7]$.Institutional aspects, both government and society, also need to be analyzed so it will not become an obstacle in ecotourism development, as well as facilities and infrastructure of ecotourism areas [5].

Ecotourism development is a concept of sustainable tourism development aimed at supporting environmental (natural and cultural) conservation efforts and increasing community participation in management, thereby providing economic benefits to local communities. Sustainable eco-tourism development aims to provide a quality experience of travelers and 
improve the qualityof life of local communities [8]. The potential of coastal and marine areas are still many that have not been utilized optimally due to the relatively low quality of human resources and the weak socio-economic conditions of coastalcommunities [9].

Ecotourism is basically based on activities done in the open, although ecotourism is not always synonymous with tourism in general. Therefore special criteria are required in selecting ecotourism attractions [10]. The management of ecotourism in the north coast of Makassarhas a big enough prospect to be developed. It refers to Regional and Space Planning (RSP) Makassar 2010-2030, the development of ecotourism utilizes the function of mangrove forest area to develop environmentally friendly tourism by preserving and managing mangrove area on the north coast of Makassar. The development of tourism in Makassar currently showed a fairly high increase, in 2013-2014 domestic tourists who came to Makassar about 2,072,538 people and 28,699 foreign tourists. In 2015, domestic tourists were $3,027,096$ people and foreign tourists around 32,385 people [11].

Environmental degradation that occurs in coastal areas of Makassar such as silting (high sedimentation) and garbage can threaten the sustainability of coastal and marine resources in that area if it is not addressed immediately. Sedimentation is very good for mangrove forests, but if the quantity is high enough, it will threaten the existence of mangrove itself. Therefore it is necessary to handle with coastal ecotourism development effort. The development of ecotourism in this area is expected to be able to integrate with the surrounding community so that it can improve the prosperity of society and environment in the north coast of Makassar. This research aimed to analyze the potential of ecology, socio-economic and supporting infrastructure for the eligibility of developing mangrove ecotourism at Bira village of Makassar.

\section{RESEARCH METHOD}

This research was conducted at Bira village of Tamalanrea Sub-district of the North Coast Makassar (Fig. 1). According to Clark and Salm, several analysis of ecotourism conditions and eligibility can be developed, such as ecological criteria, socio-economic criteria and supporting criteria [12]. Ecological criteria consists of mangrove forest diversity, uniqueness, authenticity, harmful biota, and regional status. Socioeconomic criteria consists of community acceptance, public health, culture, education, security, employment and economic benefits. While the supporting criteria consists of accessibility, electricity, clean water, telecommunication and handling of garbage.

The data obtained from the questionnaires were processed by using tabulate analysis, then calculated the score and weight of each indicator. The total of respondents' answers was multiplied by the assessment criteria (Table 1) to obtain the score of the research result (questionnaire), then it was compared with the ideal score (highest score for each answer) to obtain the score of each variable.

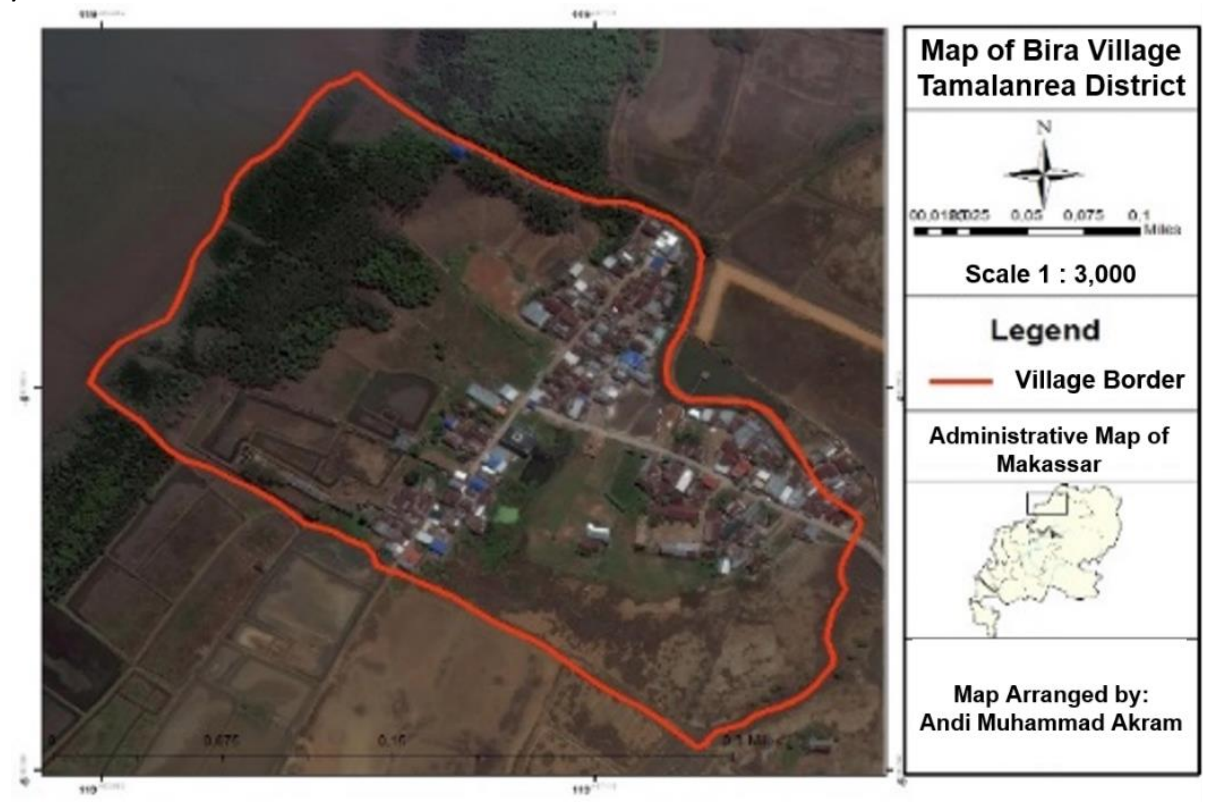

Figure 1. Map of Study Area (Source: Administrative Map of Makassar) 


$$
\text { SCORE }=\frac{\text { Total score of results }}{\text { Number of ideal scores }} x 100 \%
$$

Next weighing was done by using AHP method to determine the priority scale of each variable, the method used was paired comparison or pairwise comparison with the help of expert choice application. This method was used to determine the weight of each variable by following scale:

$\mathbf{1}$ = if the horizontal indicator was as important as the vertical

$\mathbf{3}=$ if the horizontal indicator was slightly more important than the vertical indicator

$\mathbf{5}=$ if the horizontal indicator was more important than the vertical indicator

Once the scores and weights were known then further determined the value of eligibility. The value of eligibility was determined by the number of scores obtained from the respondents' answers and multiplied by the weights.

\section{Eligibility Value $=$ Score $\mathrm{x}$ Weight}

The result of the multiplication of scores and the weights obtained was the eligibility of the research area in ecotourism development. The eligibility value was then adjusted to the standard in Table 1 to see the rating category.

Table 1. The Standards of Eligibility Values for Ecotourism Development

\begin{tabular}{ccc}
\hline Eligibility Value (\%) & \multicolumn{2}{c}{ Eligibility Category } \\
\hline $81.26-100.0$ & Very Appropriate & Very Good \\
$62.52-81.25$ & Appropriate & Good \\
$43.76-62.52$ & Less Appropriate & Less Good \\
$10.00-43.76$ & Not Appropriate & Not Good \\
\hline
\end{tabular}

Source: Tuwo [5]

\section{Data Collection}

Quantitative and qualitative data collection was done simultaneously. In this study the data collection was done by using following method.

\section{Quantitative Data}

Questionnaire, a list of questions was given to the respondents. It is used to determine the socio-economic conditions of the community includes culture and customs, education, employment, economic benefits, security, as well as acceptance and perceptions of the community on ecological conditions and supporting infrastructure of the ecotourism at Bira region.

\section{Qualitative Data}

Observation was how to collect data on direct observation at research location. Observed data were the physical condition of the environment, naturalness, cleanliness of the area, the availability of supporting infrastructure, accessibility and transportation.

Interview to complete supporting data addressed to informant as main resource for tourism object manager, i.e. Tourism Office, Research and Development Office (Bappeda) of Makassar, Fishery and Marine Office of Makassar. The information is about the opinions, directions, and government policies on ecotourism development. Documentary study was also used for collecting the literature that can help in identifying the potential of Bira Village.

\section{RESULT AND DISCUSSION}

\section{An Overview of Research Objects}

Closure of mangrove forest land from 2001 to 2015 experienced a major improvement in Makassar. The area of mangrove forest in 2001 was $50.3 \mathrm{Ha}$ while in 2015 it was $58.52 \mathrm{Ha}$. This shows the extent of the forest of mangrove had a wide increase of 8.23 or $16 \%$ of the total area of Makassar.

There are several factors that cause the expansion of mangrove forest, one of them is planting mangrove seeds. Based on the results of identification of mangrove vegetation at Bira, it was found 4 types of Mangrove, i.e. Avicennia alba, A. marina, Rhizphora mucronata and $R$. apiculata. Then, there are three important variables to analyze the eligibility criteria of ecotourism. Those are ecological eligibility, socioeconomic eligibility and supporting infrastructure facilities that must be considered.

\section{Ecological Eligibility \\ The Diversity of Natural Resources}

The results of data analysis conducted based on questionnaire data showed that the diversity of natural resources for ecotourism development at Bira Village was appropriate or good with score 80.3. The mangrove species found at Bira village were quite diverse, including Rhizophora spp., Bruguiera spp. (Tumu/Tancang), Avicennia spp. (Api-api) and Nypa fruticans (Nipah).

\section{Uniqueness}

The uniqueness of ecotourism development at Bira Village was not appropriate or not good with score value 25 according to the questionnaire. The uniqueness of Bira ecosystem value was calculated by paying attention to the flora and ecosystem which assessed by the existing in other place or not. The ecosystems at Bira Village were mangrove forest ecosystems, 
these ecosystems were widely present in coastal areas of Indonesia that had suitable conditions.

\section{Nature/Authenticity}

The results of data analysis conducted based on questionnaire data showed that the nature/ authenticity for ecotourism development at Bira is appropriate or good with score 75.8. Bira Village could be said still original or natural, but there are various efforts that must be controlled early because it may cause damage or change of land function which is not balanced with the nature.

\section{Dangerous Biota}

The results of data analysis showed that there was no dangerous biota for ecotourism development in Bira. It meant the location was very suitable or good with score value 100 . Some respondents said that there was no dangerous biota that can threaten at Bira area.

\section{Disaster Vulnerability}

The results of data analysis conducted based on questionnaire data showed that the vulnerability of disaster for ecotourism development in Bira was very suitable or very good with score 83.5. In the last 5 years, there has never been a natural disaster that could damage Bira ecosystem.

\section{Regional Status}

The results of analysis showed that the status of Bira area for ecotourism development was very appropriate or very good with score 100 . Some respondents said that Bira area was very suitable for ecotourism area.
Score assessment of ecological aspect in ecotourism development at Bira village of Makassar (Table 2). Based on the Table 2, it can be seen that the score obtained was 73.99 included in the appropriate or good category with the value of eligibility 62.52-81.25. Thus, it can be concluded that ecology in the development of ecotourism at Bira was appropriate or good. Based on the result of ecological eligibility criteria at Bira Village, the criteria of weighting conducted by using Expert Choice 2000as Statistic program for hierarchy analysis with the result presented in Figure 2.

Table 2. Ecological Aspect Scoring in Ecotourism Development at Bira Village of Makassar

\begin{tabular}{lccc}
\hline Parameter & Score & Weight & Total \\
\hline The diversity of natural & 80.3 & 0.22 & 17.66 \\
resource & & & \\
Uniqueness & 25.0 & 0.24 & 6.00 \\
Nature/authenticity & 75.8 & 0.09 & 6.82 \\
Dangerous biota & 100 & 0.08 & 8.00 \\
Disaster vulnerability & 83.5 & 0.09 & 7.51 \\
Regional status & 100 & 0.28 & 28.0 \\
\hline \multicolumn{2}{c}{ Total } & 1.00 & $\mathbf{7 3 . 9 9}$ \\
\hline \multicolumn{2}{c}{ Assessment Category } & & Appropriate \\
\hline
\end{tabular}

\section{Socio-economic Eligibility \\ Public Acceptance}

Based on the results of questionnaire data analysis, the community gave a positive response by accepting the development of Bira area into a tourist area. From the data analysis, it was known that community approval for ecotourism development at Bira was very good (88.7). Although people's understanding was still very little about the concept of ecotourism, but the desire to get to involved and expected was huge.

Priorities with respect to:

Goal: STRATEGY OF ECOTOURISM DEVELOPMENT

$>$ ECOLOGY

\author{
THE DIVERSITY OF NATURAL RESOURCE \\ UNIQUENESS \\ DANGEROUS BIOTA \\ NATURE / AUTHENTICITY \\ DISASTER VULNERABILITY \\ REGIONAL STATUS \\ Inconsistency $=\mathbf{0}$, \\ with 10 missing judgments.
}

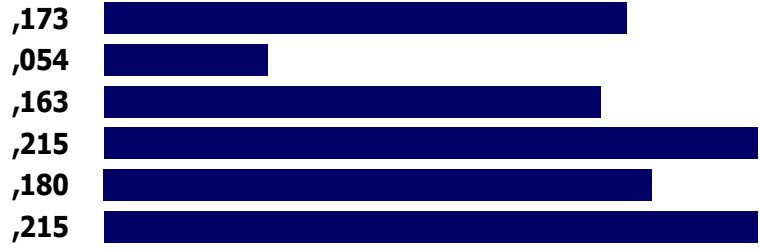

Figure 2. Weight the Value of Ecology Eligibility Criteria at Bira Village by Using Expert Choice 2000 


\section{Culture}

Based on the results of the study, there are several cultural factors namely: understanding of traditional values, involvement in ritual events, involvement in cultural events and artistic attractions, involvement in race events and hopes for the preservation of customs and culture. It has been known that the value of the eligibility or achievement of the cultural factors from society to the development of ecotourism at Bira was good with score 80.0.

\section{Level of education}

Majority of Bira urban only have elementary to high school of education level. Based on the results of data analysis conducted, it can be seen that the achievement of educational factors of Bira community was not good that was 63.4.

\section{Jobs}

Based on the results of the questionnaire, the achievement of the employment factor for the development of ecotourism at Bira area was good with 62.50. The majority of people at Bira have the least education level of elementary school up to the first level of high school.

\section{Security}

The results of data analysis showed that the achievement of community and environmental security factors could support the development of ecotourism at Bira in a very good category, with value 84.50 . The community was aware of the unavailability of environmental security facilities. Therefore, most people argued that the availability of security facilities was necessary at Bira area.

Based on the results of the analysis on socioeconomic aspects, it can be concluded that the socio-economic aspects of ecotourism development at Bira village was accordingly shown in the following table 3 , where the values obtained were included in the appropriate category. Based on the result of socio-economic eligibility criteria at Bira, the criteria weighted by using Expert Choice 2000 with the result as Figure 3.

Table 3. Score of Socio-economic Aspect in Ecotourism Development at Bira village of Makassar

\begin{tabular}{|c|c|c|c|}
\hline Parameter & Score & Weight & Total \\
\hline Public acceptance & 88.70 & 0.31 & 27.50 \\
\hline Culture & 80.00 & 0.27 & 21.60 \\
\hline Level of education & 63.40 & 0.05 & 3.17 \\
\hline Jobs & 62.50 & 0.09 & 5.62 \\
\hline Security & 84.50 & 0.28 & 23.66 \\
\hline Total & & 1.00 & 81.55 \\
\hline
\end{tabular}

Eligibility of Infrastructure and Institutional Facilities

\section{Accessibility and transportation}

The accessibility level of a region is characterized by better road conditions linking an area with other areas. The results of questionnaires for accessibility and transportation factors obtained a score of 54.3 with less appropriate category. This was indicated by the absence of public transportation planned by the government, so the access to the area can only be reached by using private vehicle or using the motorcycle taxi service.

\section{Electricity, telecommunication, clean water and garbage}

Electricity; the data for electrical conditions at Bira obtained a score of 100 with very good category. Based on the results of the study, all respondents said they had used electricity in their homes. Because of this time, Bira has already facilitated a service from State Electric Company.

Telecommunication. The conditions of telecommunication obtained a score of 95 with very good category. Some respondents said that currently they still used home phone network.

\section{Priorities with respect to: $>$ SOCIAL-ECONOMIC \\ PUBLIC ACCEPTANCE CULTURE \\ LEVEL OF EDUCATION \\ JOBS \\ SECURITY \\ Inconsistency $=\mathbf{0}$, with 6 missing judgments.} Goal: STRATEGY OF ECOTOURISM DEVELOPMENT

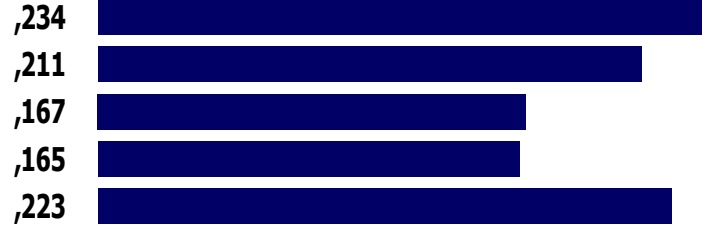

Figure 3. Weight the Value of Social-economic Eligibility Criteria at Bira Village by Using Expert Choice 2000 
Clean water. Value score of clean water conditions in the region was 100 with the category of assessment was very good. The respondents said that they already had a clean water from regional company and water wells provided by the government

Garbage. Based on the results of questionnaires, handling of garbage in a score of 63.4 with good category. Handling waste was done by way of disposal to the garbage dump and then transported by the janitor.

\section{Availability of Accommodation, Facilities and Tour Services}

Currently the availability of accommodation was still limited independent efforts of the local community by renting rooms in their homes or in other words generally tourists will stay at residents' home. Because until now there has been no special lodging development to serve tourists who aim to stay because the tourists who come were still limited to a day visit.

\section{Information, Promotion and Institutional Services}

Bira area is planned as a mangrove ecotourism area by the Tourism Office of Makassar in 2011 and also supported by the policy of Regional and Space Planning (RSP) Makassar which is currently being proposed for the making of local regulations, which directs Bira area to be developed into a tourism area that utilizes the environment, especially mangrove forest.

Based on the results of research, supporting infrastructure at Bira has being available. That is why future tourism development is very easy to be implemented because it has been supported by adequate basic facilities.

Based on the result of the eligibility criteria of supporting infrastructure, the ecotourism at Bira was weighted by using Expert Choice 2000 with the following results in Figure 4. There are

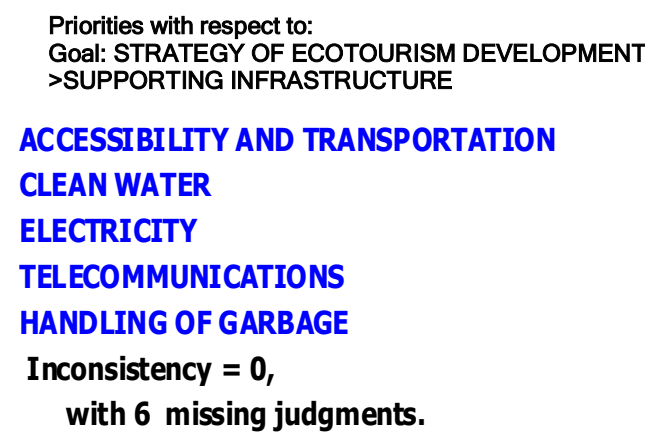

, 132 several potential diversity of natural resources for ecotourism such as beaches, mangrove forests, rice fields, rivers and ponds (Table 5). One of biodiversity utilities for people is tourism [13]. Mangrove provide habitat for many animal species such as bird. Bird is one of animal group that potential for supporting ecotourism [14]. This kind of tourism is more sustainable when local people participation involve in the tourism management [7].

Table 4. Score Assessment of Supporting Infrastructure Aspect of Ecotourism Development at Bira village of Makassar

\begin{tabular}{|c|c|c|c|}
\hline Parameter & Score & Weight & Total \\
\hline $\begin{array}{l}\text { Accessibility and } \\
\text { transportation }\end{array}$ & 54.3 & 0.41 & 22.26 \\
\hline Electricity & 100 & 0.18 & 18.0 \\
\hline Clean Water & 95.0 & 0.31 & 29.0 \\
\hline Telecommunications & 100 & 0.05 & 5.0 \\
\hline Handling of garbage & 63.4 & 0.05 & 3.17 \\
\hline Total & & 1.00 & 77.93 \\
\hline \multicolumn{2}{|c|}{ Assessment Category } & & Appropriate \\
\hline
\end{tabular}

Eligibility of Ecotourism Development in Bira Village

Based on the results of the questionnaire on the three criteria for the eligibility of ecotourism development such as ecology, socio-economic and supporting factors. It can be described in the analysis that these three criteria are important aspects of ecotourism development at Bira. The assessment of eligibility criteria of the three aspects can be seen in Table 6 . While the the eligibility criteria of ecotourism development at Bira was weighted by using Expert Choice 2000 with the following results in Figure 5.

Table 6. Ecotourism Eligibility Development at Bira Village of Makassar in 2017

\begin{tabular}{|c|c|c|c|}
\hline Parameter & Score & Weight & Total \\
\hline Ecological aspect & 73.99 & 0.50 & 37.00 \\
\hline Socio-economic & 81.55 & 0.30 & 24.46 \\
\hline Supporting infrastructure & 77.93 & 0.20 & 15.60 \\
\hline $\begin{array}{c}\text { Total } \\
\end{array}$ & & 1.00 & 77.06 \\
\hline \multicolumn{2}{|c|}{ Assessment Category } & & propri \\
\hline
\end{tabular}

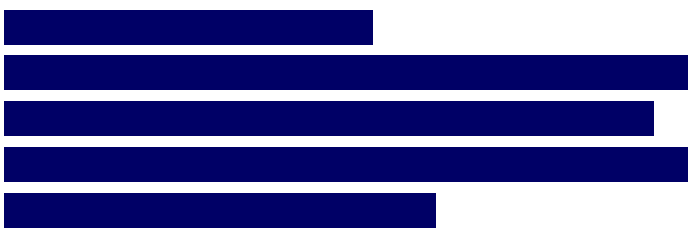

Figure 4. Weight of the Ecotourism Eligibility Criteria at Bira by Using Expert Choice 2000 
Ecotourism Eligibility in the North Coast of Makassar

(Akram et al.)

Table5. The Analysis of Eligibility Criteria of Supporting infrastructure at Bira Village in 2017

\begin{tabular}{|c|c|c|c|}
\hline No & Parameter & Appropriate Condition & Existing Condition \\
\hline \multirow{8}{*}{1} & Ecology Criteria & & \\
\hline & The diversity of natural resource & Good (5-6) & $\begin{array}{l}\text { There are several potential natural resources } \\
\text { of ecotourism such as beaches, mangrove } \\
\text { forests, rice fields, rivers and ponds }\end{array}$ \\
\hline & Uniqueness & & $\begin{array}{l}\text { In general the same as mangrove ecosystem in } \\
\text { Indonesia }\end{array}$ \\
\hline & Dangerous biota & No harmful biota & No harmful biota is found in the region \\
\hline & Nature/authenticity & The condition is still natural & $\begin{array}{l}\text { The condition is still natural even though there } \\
\text { are some places that have got human } \\
\text { intervention }\end{array}$ \\
\hline & Regional characteristics & Loud and sandy/muddy & $\begin{array}{l}\text { In the form of mangrove ecosystems and } \\
\text { ponds that contains the river. Coastal } \\
\text { characteristics tend to advance (increase) } \\
\text { toward the sea due to sedimentation from the } \\
\text { river }\end{array}$ \\
\hline & Disaster vulnerability & Safe from disaster threats & $\begin{array}{l}\text { Within } 5 \text { years there has never been a natural } \\
\text { disaster }\end{array}$ \\
\hline & Regional status & Conservation area & Including areas of utilization and rehabilitation \\
\hline \multirow{6}{*}{2} & Socioeconomic Criteria & & \\
\hline & Public acceptance & Very Good & $\begin{array}{l}\text { The acceptance of the community is very good } \\
\text { and supports the activity of the development } \\
\text { of the area into a tourist area }\end{array}$ \\
\hline & Culture and customs & Good & $\begin{array}{l}\text { Cultural activities and customs are still often } \\
\text { done by the community, especially ritual } \\
\text { activities }\end{array}$ \\
\hline & $\begin{array}{l}\text { Education and understanding of } \\
\text { ecotourism }\end{array}$ & Good & $\begin{array}{l}\text { The level of community education is still low. } \\
\text { Understanding in terms of ecotourism is also } \\
\text { still minimal. }\end{array}$ \\
\hline & Jobs & Good & $\begin{array}{l}\text { Employment is still lacking and there is an } \\
\text { opportunity for new and better jobs }\end{array}$ \\
\hline & Security & Very Safe & $\begin{array}{l}\text { Never experiences any internal or external } \\
\text { conflict }\end{array}$ \\
\hline \multirow{6}{*}{3} & Supporting Criteria & & \\
\hline & Accessibility & Easy to access & $\begin{array}{l}\text { Still needs additional facilities and } \\
\text { infrastructure that support the development } \\
\text { of ecotourism }\end{array}$ \\
\hline & Clean water & Clean water was available & $\begin{array}{l}\text { Clean water is available in the form of PDAM } \\
\text { and dug wells }\end{array}$ \\
\hline & Electricity & Available & $\begin{array}{l}\text { The power grid has been well accommodated } \\
\text { for one Bira village }\end{array}$ \\
\hline & Telecommunication & Available & $\begin{array}{l}\text { Telecommunication network is very good, has } \\
\text { been available cellular telecommunication } \\
\text { channel and signal pretty good. }\end{array}$ \\
\hline & Institutional & $\begin{array}{l}\text { There was a tourism } \\
\text { management agency }\end{array}$ & $\begin{array}{l}\text { The institutional system has not been well } \\
\text { organized but there are various community } \\
\text { institutions (LPM) that provide training. }\end{array}$ \\
\hline
\end{tabular}

Priorities with respect to:

Goal: STRATEGY OF ECOTOURISM DEVELOPMENT

ECOLOGY

SOCIAL-ECONOMIC

SUPPORTING INFRASTRUCTUR

Inconsistency $=0$, with 1 missing judgment.
317

349

, 334

Figure 5. Weight of the Ecotourism Eligibility Criteria at Bira Village by Using Expert Choice 2000 
Based on the results of the analysis of the three parameters of ecology, socio-economic and supporting factors, it can be concluded that the north coast areas of BIra Village are eligible and appropriate for the development of ecotourism. This can be seen from the criteria of the three aspects that suit and meet the qualifications or can be said good. To that end, Bira village that has been implemented village tourism program needs a suitable strategy to increase the capacity and the quality of the area into an area with tourism attraction, especially in terms of the development of tourist areas based on the environment, given the potential of natural resources in the region. Bira Village alone has an ecological function but also has an economical function so that in its development it is necessary to preserve it so that resources can still function to balance the environment and still be enjoyed by future generations. To achieve the ecotourism goal, socialization programs, promotion, cooperation, community participation in the event ecotourism that must emphasize supervision, conservation and protection of natural resource $[6,7,15,16]$.

\section{CONCLUSION}

Based on the criteria analysis of the three parameters: ecological aspect, socio-economic aspect and supporting infrastructure aspect, it is concluded that Bira was eligible site for ecotourism development with the total value of 77.06 .

\section{REFERENCES}

[1] Pigram, J. J. and S. Wahab (Eds). 2005. Tourism, development and growth: the challenge of sustainability. Routledge.

[2] Bunruamkaew, K. 2011. Site suitability evaluation for ecotourism using GIS and AHP: a case study of Surat Thani Province, Thailand. Procedia - Social and Behavioral Sciences 21, 269-278.

[3] Wight, P. A. 2002. Supporting the principles of sustainable development in tourism and ecotourism: government's potential role. Current Issues in Tourism 5(3-4), 222-244.

[4] Kumari, S., M.D. Behera and H.R. Tewari.2010. Identification of potential ecotourism sites in West District, Sikkim using geospatial tools. Tropical Ecology 51(1), 75-85.

[5] Pforr, C. 2001. Concepts of sustainable development, sustainable tourism, and ecotourism: Definitions, principles, and linkages. Scandinavian Journal of Hospitality and Tourism 1(1), 68-71.

[6] Parmawati, R.,A. S. Leksono, B. Yanuwiadi and A. S. Kurnianto. 2017. Exploration of marine tourism in Watulimo, Trenggalek Regency: challenges, potentials, and development strategies. Journal of Indonesian Tourism and Development Studies 5(3), 175-184.

[7] Antonius, A. Suman, A. S. Leksono,H.Riniwati. 2018.Ecotourism management strategy of peat swamp forest in Baning Nature TouristPark Area in West Kalimantan Indonesia. IOSR Journal of Business and Management 20(1), 78-83.

[8] Fennell, D.A. 2008. Ecotourism: an introduction, $3^{\text {rd }}$ Ed. Routledge. New York.

[9] Budiharsono, D. 2001. Teknik analisis pembangunan wilayah pesisir dan lautan. Prandnya Paramita. Jakarta.

[10] Hakim, L. 2004. Dasar-dasar ekowisata. Bayumedia.

[11] Bugisposonline. 2016. Visit Makassar and beyond 2013-2016. Available at: www.bugisposonline.com.

[12] Clark, J.R. and R.V. Salm. 2000. Marine And coastal protected areas. International Union for Concervation of Nature and Natural Resources Gland. Switzerland.

[13] Leksono, A.S. 2011. Keanekaragaman hayati. University of Brawijaya Press. Malang.

[14] Muttaqien, H. Z., L. Hakim, A. S. Leksono. 2015. Analysis of bird diversity for supporting ecotourism development in Rajegwesi, Meru Betiri National Park. Journal of Indonesian Tourism and Development Studies 3(3), 105-110.

[15] Hakim, L., M. Soemarno and S. K. Hong. 2012. Challenges for conserving biodiversity and developing sustainable island tourism in North Sulawesi Province, Indonesia. Journal of Ecology and Environment 35(2), 61-71.

[16] Sebele, L. S. 2010. Community-based tourism ventures, benefits and challenges: Khama Rhino sanctuary trust, central district, Botswana. Tourism Management 31(1), 136-146. 